http://journal.uinsgd.ac.id/index.php/biodjati

\title{
ISOLATION AND IDENTIFICATION OF HYDROCARBON-DEGRADING BACTERIA THAT TOLERANT TO SAPONIN OF Sapindus rarak PLANT
}

\author{
Evi Octaviany ${ }^{1}$, Suharjono ${ }^{2}$, Irfan Mustafa ${ }^{* 3}$
}

\begin{tabular}{l} 
Received : March 22, 2019 \\
Accepted : April 29, 2019 \\
\hline DOI: $\mathbf{1 0 . 1 5 5 7 5 / b i o d j a t i . v 4 i 1 . 4 3 9 2}$
\end{tabular}

1,2,3 Department of Biology, Faculty of Mathematics and Natural Sciences, Universitas Brawijaya, Malang 65145, telp/fax. 0341-575841

e-mail:

1evy.octafiany@gmail.com

²sharjono@gmail.com

*3irfan@ub.ac.id

*Corresponding author
Abstract. A commercial saponin as biosurfactant can reduce the surface tension of water and increase of hydrocarbon degradation. However, this saponin can be toxic to some hydrocarbonoclastic bacteria. This study aimed to obtain bacterial isolates that were tolerant and incapable to degrade saponin, and to identify them based on $16 \mathrm{~S}$ rDNA sequence. Bacteria were isolated from petroleum contaminated soil in Wonocolo Village, Bojonegoro Regency, East Java, Indonesia. The soil samples were acclimated using Bushnell-Haas (BH) broth with $0.5 \%$ crude oil at room temperature for 3 weeks. The culture was spread onto $\mathrm{BH}$ agar incubated at $30^{\circ} \mathrm{C}$ for 7 days. The first screened, isolates were grown in nutrient broth with addition of saponin $0 \%, 8 \%$, and $12 \%(\mathrm{v} / \mathrm{v})$ then incubated at $30^{\circ} \mathrm{C}$ for three days. The bacterial cell density was measured using a spectrophotometer. Second screened, the isolates were grown on BH broth with addition of $0.5 \%$ saponin as a sole carbon source, and their cell densities were measured. The selected isolates were identified based on $16 \mathrm{~S}$ rDNA sequences. Among 34 bacterial isolates, nine isolates were tolerant to 12\% saponin. Three bacterial isolates IHT1.3, IHT1.5, and IHT3.24 tolerant to high concentration of saponin and did not use this substance as growth nutrition. The IHT1.3, IHT1.5, and IHT3.24 isolates were identified as Ochrobactrum pseudogrignonense (99\% similarity), Pseudomonas mendocina (99\%), and Ochrobactrum pituitosum; (97\%), respectively. Those three selected isolates are good candidates as hydrocarbon-degrading bacteria to bioremediation of soil contaminated crude oil. However, the combined activity of bacteria and saponin to degrade hydrocarbon needs further study.

Keywords: Ochrobactrum pituitosum, Ochrobactrum pseudogrignonense, sapindus rarak plant, saponin commercial, Pseudomonas mendocina

\section{Citation}

Octaviany, E., Suharjono \& Mustafa, I. (2019). Isolation and Identification of Hydrocarbon-Degrading Bacteria that Tolerant to Saponin of Sapindus rarak Plant. Jurnal Biodjati, 4(1), 79-88

\section{INTRODUCTION}

Indonesia is one of the countries in the world that has a lot of petroleum reserves. Petroleum reserves, in 2016 were approxi- mately 3.6 billion barrels and half of them are located in East Java Province (Kompas, 2016). Bojonegoro Regency, Wonocolo Village, as one of the petroleum producing areas in East Java Province is known to have 


\section{JURNAL BIDDJATI}

http://journal.uinsgd.ac.id/index.php/biodjati

several petroleum wells which cause pollution to the soil. Petroleum contaminated soil can be used as a carbon source for microorganism growth, such as hydrocarbonoclastic bacteria, fungi and yeast (Chikere \& Azubuike, 2014). Application of hydrocarbonoclastic bacteria is cost-efficient and environmental friendly (Quatrini et al., 2008). Hydrocarbonoclastic bacteria can oxidize various types of hydrocarbon compounds by producing biosurfactant (Kostka et al., 2011).

Biosurfactants aren't only produced by bacteria but also produced by plants (Guo et al., 2008). Sapindus rarak can produce compounds in the form of saponins. Saponins can be obtained by extracting the plants themselves or available commercially. Commercial saponins are popular traditional detergent product among local people, used as batik washing material in Indonesia. There are many benefits from saponin application, especially in the field of biotechnology. Saponins can decrease water surface tension and it is less harmful (Kobayashi et al., 2012). In previous research, the interaction between Sphingomonas sp. and saponins $0.25 \%-5 \%$, obtained from Sapindus mukorossi plants was able to increase degradation of pyrene and phenanthrene (aromatic hydrocarbons) (Kobayashi et al., 2012). Other studies also mentioned that combination treatment of 5\% commercial saponins and bacteria increased hydrocarbon degradation (Soeder et al., 1996).

However, not the whole extract saponins from each plants species can synergize with the hydrocarbonoclastic bacteria. This has been proven by other studies, where saponin extract from some plants was toxic to bacterial cells from the rumen of sheep and ruminants. Some of the plants are Sesbania sesban, Quillaja saponaria, Acacia auriculiformis, Sapindus saponaria and Enterolobium cyclocarpum (Guo et al., 2008). So, the pur- pose of this study was to isolate bacteria based on the level of tolerance to saponins and don't have degradation activity of saponins.

\section{MATERIALS AND METHODS}

\section{A Sampling of Hydrocarbon from Contam- inated Soil}

Soil samples were collected from traditional petroleum mining at Wonocolo Village, Bojonegoro Regency, East Java Province, Indonesia. Petroleum contaminated soil were taken from three-sites at $0-10 \mathrm{~cm}$ depth below the soil surface using a sterile shovel (Panda \& Sarkar, 2012). Soil sample at each sampling site was taken randomly from five points and composite as one soil sample. Soil samples were collected into a labeled plastic bag and put into a cool box containing ice cubes. The soil samples were then taken to the laboratory within 18 hours.

\section{Isolation and Enrichment of Hydrocarbon- oclastic Bacteria}

Soil samples as much as $2 \mathrm{~g}$ suspended in $100 \mathrm{~mL} \mathrm{BH}$ broth in the Erlenmeyer flask $250 \mathrm{~mL}, 0.5 \%$ crude oil at $\mathrm{pH} 6.8$ were then added. The $\mathrm{BH}$ broth medium consist of 0.85 $\% \mathrm{NaCl}, 0.02 \mathrm{~g} / \mathrm{L} \mathrm{MgSO} 4,0.002 \mathrm{~g} / \mathrm{L} \mathrm{CaCl}$, $0.1 \mathrm{~g} / \mathrm{L} \mathrm{KNO} 3,0.05 \mathrm{~g} / \mathrm{L} \mathrm{FeCl3}, 3.6 \mathrm{~g} / \mathrm{L} \mathrm{K} 2 \mathrm{H}-$ PO4, $1.2 \mathrm{~g} / \mathrm{L} \mathrm{KH} 2 \mathrm{PO} 4$ and 1.0 liter of distillation water (Udgire et al., 2015). The cultures were incubated at room temperature on shaker incubator $120 \mathrm{rpm}$ for 7 days. $5 \mathrm{~mL}$ of culture suspension was inoculated into $\mathrm{BH}$ broth medium and it conducted three times. The culture enrichment was done to obtain the most effective strains of hydrocarbon degrading bacteria (Udgire et al., 2015). The $0.1 \mathrm{~mL}$ of culture suspension at $10-7$ dilution in $0.85 \%$ sodium chloride solution was spread on $\mathrm{BH}$ agar with the addition of crude oil. The culture was incubated at $30^{\circ} \mathrm{C}$ for a week. 


\section{Jurnal Biodjati 4(1):79-88, May 2019 \\ JURNAL BI@DIATI}

http://journal.uinsgd.ac.id/index.php/biodjati

\section{Screening of Hydrocarbonoclastic Bacteria}

Pure culture of each isolate was screened in a two-step. The first step, bacteria inoculated into the nutrient broth with added by $0,0.5,8.0$ and $12.0 \%$ of saponin (Soeder et al., 1996). The culture was then incubated at room temperature in shaker incubator 120 rpm for 20 hours. The optical density of each isolate was adjusted to get similar cell density. Each bacterial culture with similar cell density of approximately $3 \mathrm{~mL}$ was inoculated into $27 \mathrm{~mL}$ of nutrient broth containing saponins 0,8 and $12 \%$. The culture incubated at room temperature in shaker incubator $120 \mathrm{rpm}$ for 3 days. The growth of the bacterial isolates was measured using a spectrophotometer at 600 $\mathrm{nm}$ wavelength (Al-Wasify \& Hamed, 2014). The Isolates that were able to growth in nutrient broth with a high concentration of saponins to be used for the next screening. The second step, suspension of bacteria culture was inoculated into $\mathrm{BH}$ broth with the addition of $0.5 \%$ of saponin as a sole carbon source and it was incubated at room temperature on shaker incubator $120 \mathrm{rpm}$ for 20 hours. The suspension of $3 \mathrm{~mL}$ bacterial culture with similar cell density was inoculated into $27 \mathrm{~mL}$ $\mathrm{BH}$ broth containing $0.5 \%$ saponin. The culture incubated at room temperature in shaker incubator $120 \mathrm{rpm}$ for 3 days. The bacterial cell density was measured using a spectrophotometer at $600 \mathrm{~nm}$ wavelength (Al-Wasify \& Hamed, 2014). The selected bacteria isolate was determined based on the highest ability to growth in $\mathrm{BH}$ broth with contain hydrocarbon and highest concentration of saponin and it could not able to use of saponin as a sole carbon source.

\section{Identification of Bacteria Based on $16 \mathrm{~S}$ rDNA Sequence Similarity}

The chromosomal DNA of selected bacteria was isolated using i-genomic DNA
Extraction Soil Mini Kit from gene aid Biotechnology, Inc. The 16S rDNA sequence was amplified using 16S rDNA universal primers, 27f (5'-GAG AGT TTG ATC CTG GCT CAG $\left.-3^{\prime}\right)$ and 1495 r (5'- CTA CGG CTA CCT TGT TAC GA -3') (Gochhait et al., 2007). The amplification of $16 \mathrm{~S}$ rDNA sequence using Polymerase Chain Reaction machine. The PCR procedure was started with initial denaturation at $94^{\circ} \mathrm{C}$ for 5 minutes, it continued with total 35 cycles of denaturation $\left(94^{\circ} \mathrm{C} ; 30\right.$ $\mathrm{s})$, annealing $\left(52^{\circ} \mathrm{C}\right.$ for $\left.30 \mathrm{~s}\right)$ and elongation $\left(72^{\circ} \mathrm{C} ; 1.5 \mathrm{~h}\right)$ and final elongation at $72^{\circ} \mathrm{C}$ for 7 minutes (Promega, 2016). The amplicon of $16 \mathrm{~S}$ rDNA sequence was visualized using $1.5 \%$ agarose gel electrophoresis.

\section{Statistical Analysis}

All of the data results were statistically analyzed using One Way Analysis of Variance (ANOVA) by SPSS 16.0 software for windows with significant level $p$-value $<0.05$.

1 st-BASE of amplicons sequencing at PT. Genetika Science, Jakarta. Afterward, the sequences were used to identify the bacteria using BLAST nucleotides from NCBI. The identified isolates were compared to the reference sequences from the GenBank database to construct the phylogeny tree using MEGA 5 software for windows based on the Neighbor-Joining algorithm and Tamura-Nei model.

\section{RESULTS AND DISCUSSION}

\section{Isolates of Hydrocarbonoclastic Bacteria from Petroleum-Polluted Soil}

The total of 34 bacterial isolates were found from Petroleum-Polluted Soil that could growth on $\mathrm{BH}$ agar containing crude oil. Those isolates consist of 6 isolates of Gram-positive and 28 isolated of Gram-negative and cellshape consist of 6 isolates of coccus and 28 isolates of rod (Table 1). The whole of isolates 


\section{Jurnal Biodjati 4(1):79-88, May 2019 \\ JURNAL BIODJATI}

http://journal.uinsgd.ac.id/index.php/biodjati

have morphology of colony spherical shaped, entire margin and 18 isolates flat-elevation, while 16 isolates have an elevation-convex.
A lot of isolates that were isolated from petroleum contaminated soil samples it was due to the enrichment process that carried out 3 times.

Table 1. Macros and micro characteristics of bacteria isolated from petroleum contaminated soil in Wonocolo Village, Bojonegoro Regency

\begin{tabular}{|c|c|c|c|c|c|c|c|}
\hline \multicolumn{6}{|c|}{ Colony characteristic } & \multicolumn{2}{|c|}{ Cell characteristic } \\
\hline Isolate & Shape & Elevation & Margin & Pigmentation & Diameter & Shape & Gram \\
\hline IHT1.1 & circular & flat & entire & white & 0.52 & coccus & + \\
\hline IHT1.2 & circular & flat & entire & white & 0.52 & rod & - \\
\hline IHT1.3 & circular & convex & entire & $\tan$ & 0.63 & rod & - \\
\hline IHT1.4 & circular & convex & entire & cream & 0.54 & coccus & - \\
\hline IHT1.5 & circular & convex & entire & cream & 0.47 & rod & - \\
\hline IHT1.6 & circular & flat & entire & white & 0.42 & rod & + \\
\hline IHT1.7 & circular & flat & entire & cream & 1.27 & rod & + \\
\hline IHT2.1 & circular & convex & entire & white & 0.26 & rod & - \\
\hline IHT2.2 & circular & flat & entire & white & 1.13 & rod & - \\
\hline IHT2.3 & circular & convex & entire & cream & 1.20 & coccus & - \\
\hline IHT3.1 & circular & flat & entire & white & 0.77 & rod & - \\
\hline IHT3.2 & circular & flat & entire & white & 0.78 & rod & - \\
\hline IHT3.3 & circular & convex & entire & white & 1.12 & $\operatorname{rod}$ & - \\
\hline IHT3.4 & circular & convex & entire & $\tan$ & 0.39 & coccus & - \\
\hline IHT3.5 & circular & flat & entire & $\tan$ & 1.43 & rod & - \\
\hline IHT3.6 & circular & convex & entire & white & 0.75 & rod & - \\
\hline IHT3.7 & circular & flat & entire & white & 1.97 & rod & - \\
\hline IHT3.8 & circular & convex & entire & cream & 0.46 & rod & - \\
\hline IHT3.9 & circular & flat & entire & cream & 1.13 & rod & - \\
\hline IHT3.10 & circular & flat & entire & white & 1.30 & rod & - \\
\hline IHT3.11 & circular & convex & entire & white & 0.55 & rod & - \\
\hline IHT3.12 & circular & flat & entire & white & 1.24 & rod & + \\
\hline IHT3.13 & circular & flat & entire & cream & 1.18 & rod & + \\
\hline IHT3.14 & circular & convex & entire & white & 2.16 & $\operatorname{rod}$ & - \\
\hline IHT3.15 & circular & flat & entire & white & 1.44 & coccus & + \\
\hline IHT3.16 & circular & convex & entire & cream & 0.32 & coccus & - \\
\hline IHT3.17 & circular & flat & entire & $\tan$ & 2.28 & rod & - \\
\hline IHT3.18 & circular & flat & entire & white & 2.09 & rod & - \\
\hline IHT3.19 & circular & convex & entire & $\tan$ & 1.12 & rod & - \\
\hline IHT3.20 & circular & convex & entire & cream & 0.33 & rod & - \\
\hline IHT3.21 & circular & flat & entire & cream & 1.76 & rod & - \\
\hline IHT3.22 & circular & convex & entire & white & 0.75 & rod & - \\
\hline IHT3.23 & circular & flat & entire & white & 1.94 & rod & - \\
\hline IHT3.24 & circular & convex & entire & $\tan$ & 0.46 & rod & - \\
\hline
\end{tabular}




\section{Jurnal Biodjati 4(1):79-88, May 2019 \\ JURNAL BI@DIATI}

http://journal.uinsgd.ac.id/index.php/biodjati

The Selection of Hydrocarbonoclastic Bacteria

Hydrocarbonoclastic bacteria were selected based on ability to growth on nutrient broth medium with the addition of saponin. At the first screening, 9 isolates namely IHT1.3, IHT1.5, IHT3.8, IHT3.14, IHT3.17, IHT3.19, IHT3.20, IHT 3.23 and IHT3.24 growth better than other isolates (Figure 1a, b, c). Futhermore, those 9 isolates were screened for second stage.

a.

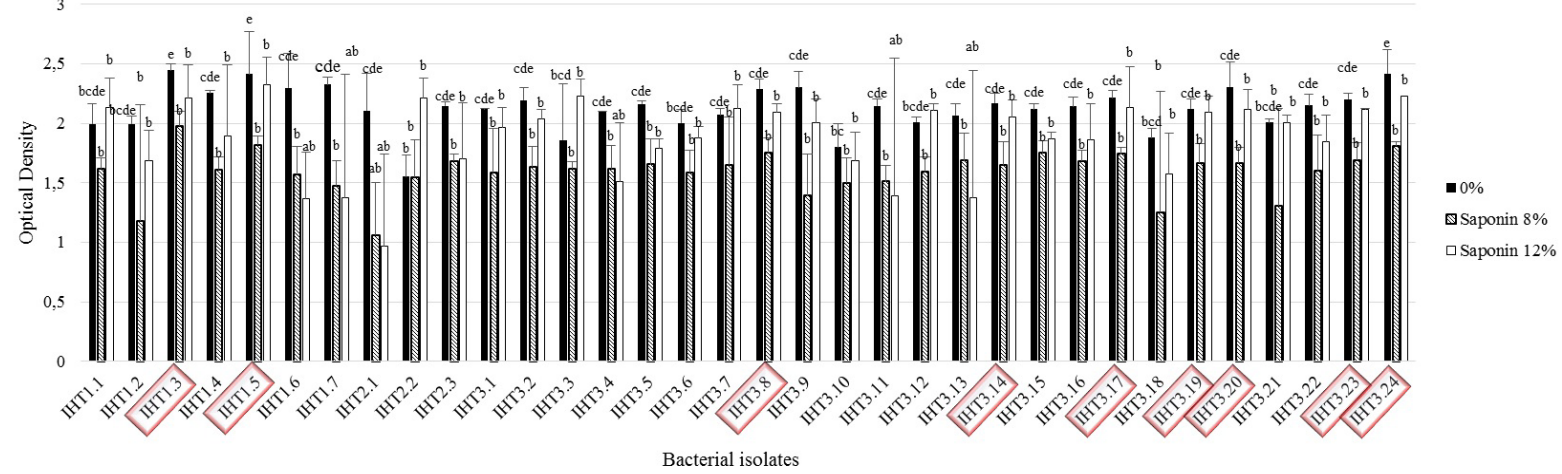

b.

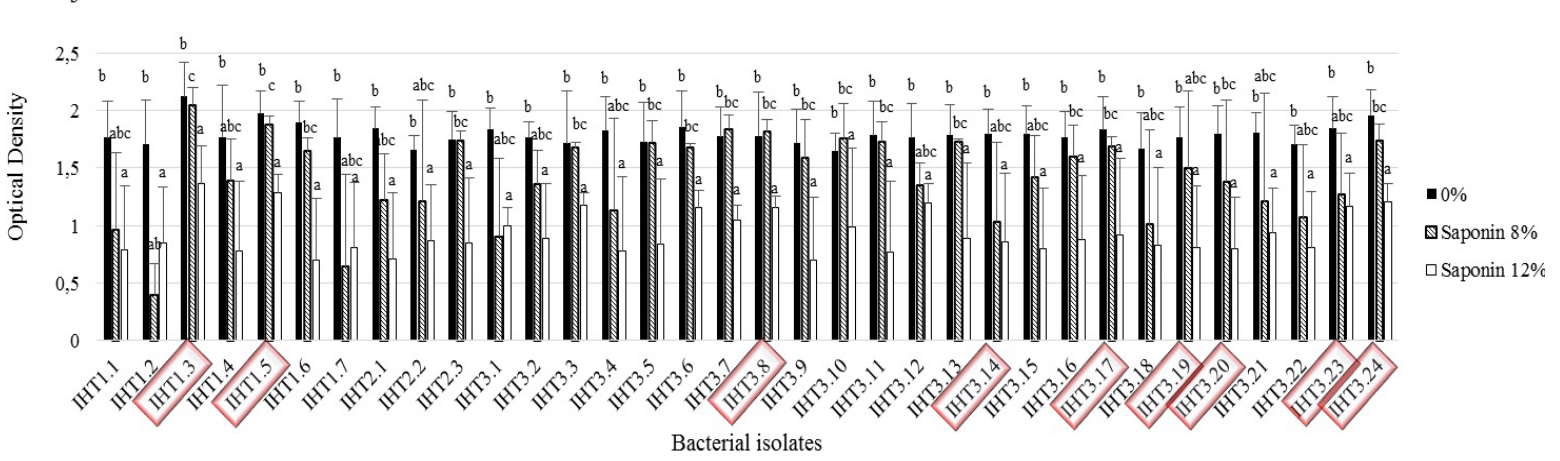

c.

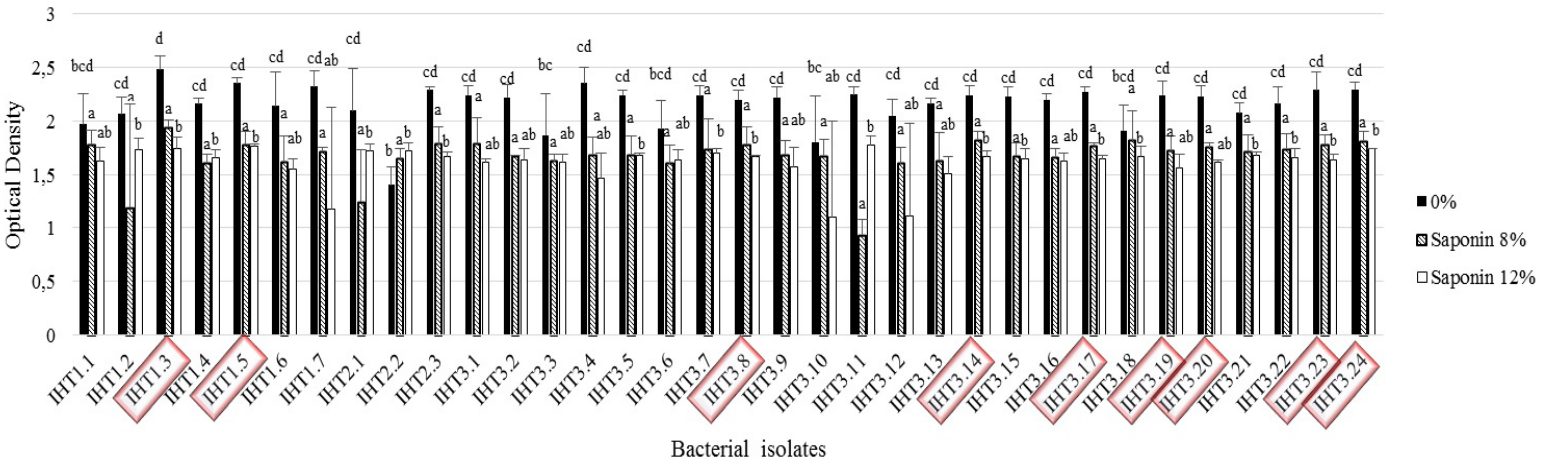

Figure 1. Cell density of Hydrocarbonoclastic bacteria on nutrient broth with the addition of saponin first day (a), second day (b), and third day (c) incubation time 


\section{JURNAL BIDDJATI}

http://journal.uinsgd.ac.id/index.php/biodjati

The hydrocarbonoclastic bacteria was growth significantly at the first day on the nutrient broth containing saponin. Whereas, cell density of those hydrocarbonoclastic bacteria did not differ significantly at second and third day of incubation, it caused by the bacteria culture was at a stationary growth phase. This means that the number of new cells is equal to the number of cells that die or its growth completely stopped and generate stationary growth (Marecik et al., 2012). This is due to lack of nutrients and decreasing of medium $\mathrm{pH}$, so the bacterial cell change physiologically. This change aims to let cells survive on a longer period of time or in unfavorable condition (Carrero-Colón et al., 2006). This stationary growth phase was evidenced by the absence of significant growth (increase cell density significantly) at the second and third days of incubation time (Figure $1 \mathrm{~b} \& 1 \mathrm{c}$ ). The presence of saponin at some concentrations, didn't have a negative impact on bacterial cell growth. Saponin from various plants caused a wide range of cell toxicity mechanism from molecular to cellular level (Guo et al., 2008). However, the 9 selected isolates were able to grow well in this condition, it showed that the bacteria have resistance to high concentrations of saponin. Whereas from other studies it was explained that saponins with a concentration of $10 \%$ can have a toxic effect on bacterial cells (Kobayashi et al., 2012). This experiment showed that saponins with high concentrations of up to $12 \%$ did not negatively affect to the Hydrocarbonoclastic bacteria. So, when combined with bacteria to degrade hydrocarbons, these saponins don't damage bacterial cells rather accelerate the rate of degradation. Those selected of Hydrocarbonoclastic bacteria were assayed for the growth activity on $\mathrm{BH}$ broth medium with saponin as a sole carbon source (Figure 2).

The second stage, the 9 bacterial iso- lates were inoculated into $\mathrm{BH}$ broth containing $0.5 \%$ concentration of saponin (Al-Wasify \& Hamed, 2014). The result showed that 3 isolates (IHT1.3, IHT1.5 and IHT3.24) of hydrocarbonoclastic bacteria were unable to use saponin as sole carbon source for growth nutrition. Those isolates have cell density similarly over three day incubation time, the optical density less than 0.1 (Figure 2). While six isolates of hydrocarbonoclastic bacteria were growth significantly at first day of incubation and it cell density decrease significantly at the second and third of incubation time. Those six isolates showed able to used saponin as a sole carbon source for growth nutrition. So those six isolates were not selected as a candidate of hydrocarbonoclastic bacteria. While the other three isolates of hydrocarbonoclastic bacteria were selected based on ability to growth on $\mathrm{BH}$ broth medium contain saponin at high concentration and cannot use saponin as a sole carbon source as growth nutrition.

\section{The Species of Selected Hydrocarbonoclas- tic Bacteria Based on Phylogeny Identifica- tion}

The three isolated of hydrocarbonoclastic bacteria Namely IHT1.3, IHT1.5, and IHT3.24 were identified phylogenetically base on 16S rDNA sequence similarity. The figure showed that IHT1.3 and IHT3.24 isolate have higher concentration of 16S rDNA sequence than IHT1.5 (Figure 3) (Lorenz, 2012). The IHT1.3 and IHT 3.24 were identified as Ochrobactrum (Table 1, Figure 4a \& 4 c) and IHT1.5 identified as Pseudomonas (Table 1, Figure $4 \mathrm{~b}$ ). Those IHT1.3 and IHT 3.24 isolate was identified as Ochrobactrum pseudogrignonense (99\% similarity) and Ochrobactrum pituitosum (97\%), while IHT 1.5 isolate as Pseudomonas mendocina ( $99 \%$ similarity).

In the process biodegradation of oil, bacteria must have a mobile genetic elements 


\section{Jurnal Biodjati 4(1):79-88, May 2019 \\ JURNAL BI@DIATI}

http://journal.uinsgd.ac.id/index.php/biodjati

(MGEs) such as plasmids. In the plasmid of hydrocarboclastic bacteria, it contain operon that coding some enzymes to degrade of hydrocarbon. Catabolic plasmids that responsible for degradation of hydrocarbon namely incP-9 or Incompatibilities (inc) Plasmid21. Plasmid incP-9 plays to start the process of degradation of oil. Other research explain that the IncP-9 plasmids detected in the Genus of Ochrobactrum and Pseudomonas (Dealtry et al., 2018). From the results of this research obtained three isolates belonging to the Genus of Ochrobactrum and Pseudomonas. These species can be used to biodegrade oil in the environment. Among 34 isolates of hydrocarbonoclastic bacteria, 3 isolates IHT1.3, IHT1.5, and IHT3.24 were crude oil and saponin tolerant and did not utilize saponin as a carbon source. Those isolates were identified as Ochrobactrum pseudogrignonense, Pseudomonas mendocina and Ochrobactrum pituitosum. The saponin of Sapindus rarak can be used as biosurfactants for supporting those selected bacteria to degrade of hydrocarbon and it can be used as a candidate of bioremediation agent of petroleum-polluted environment.

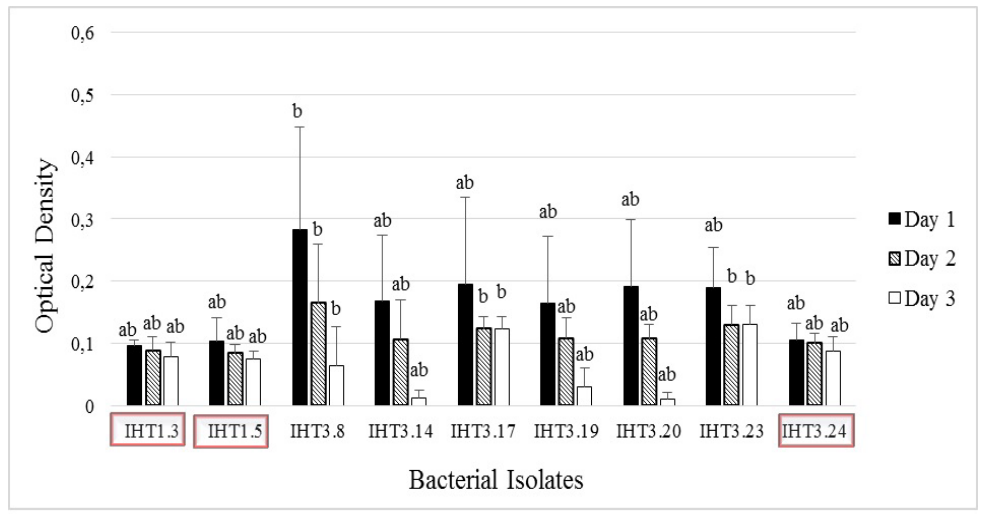

Figure 2. Cell density of Hydrocarbonoclastic bacteria on BH broth with $0.5 \%$ concentration of saponin

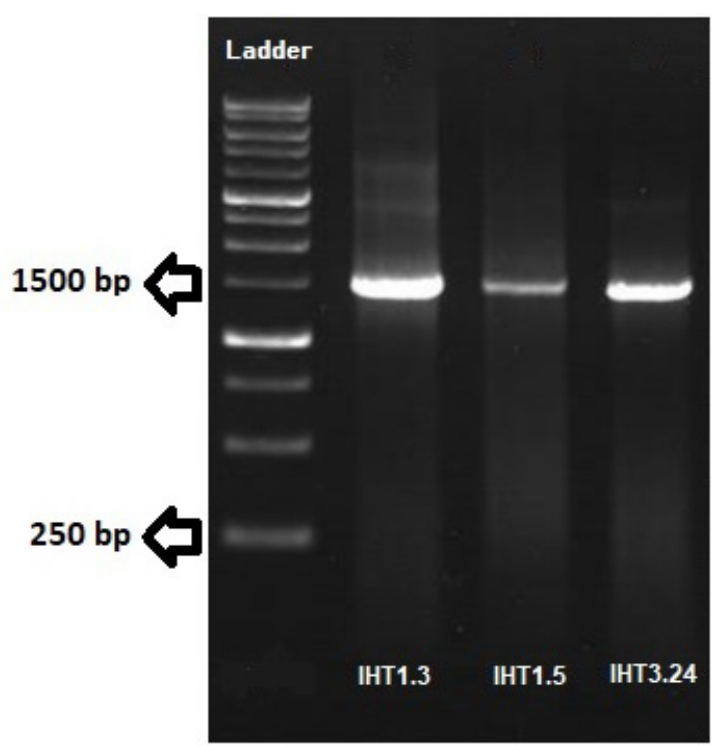

Figure 3. Amplicon of $16 \mathrm{~S}$ rDNA 


\section{JURNAL BIDDJATI}

http://journal.uinsgd.ac.id/index.php/biodjati

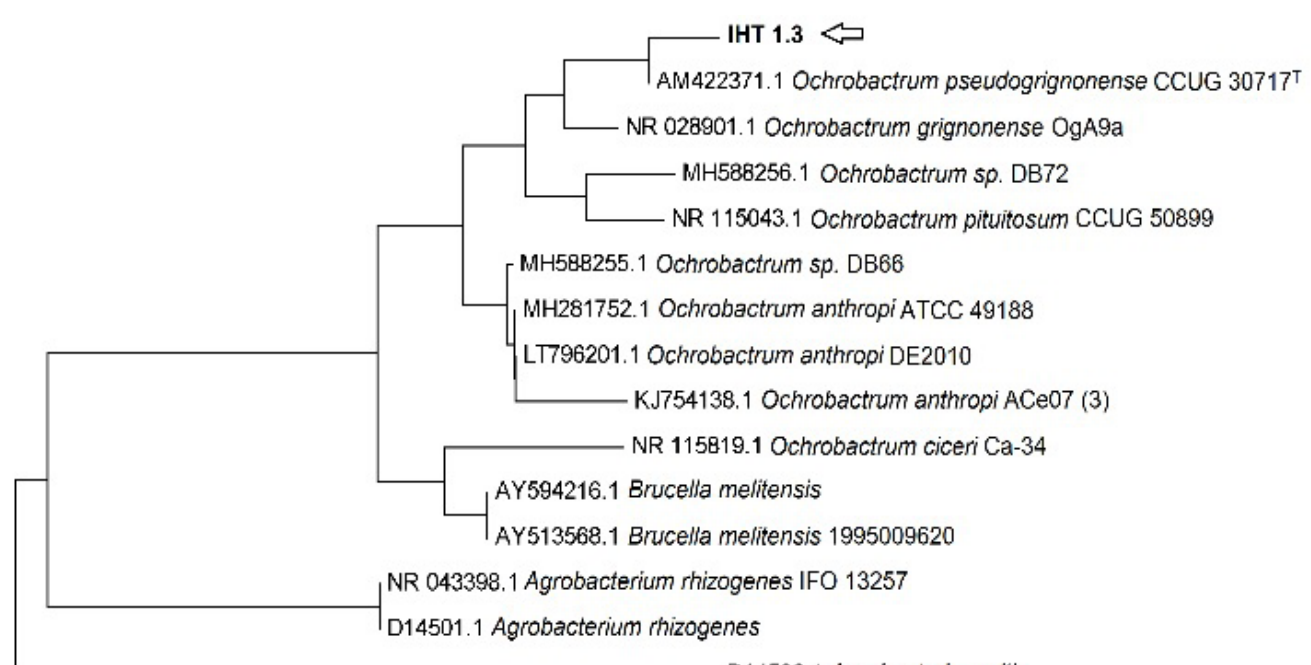

D14502.1 Agrobacterium vitis

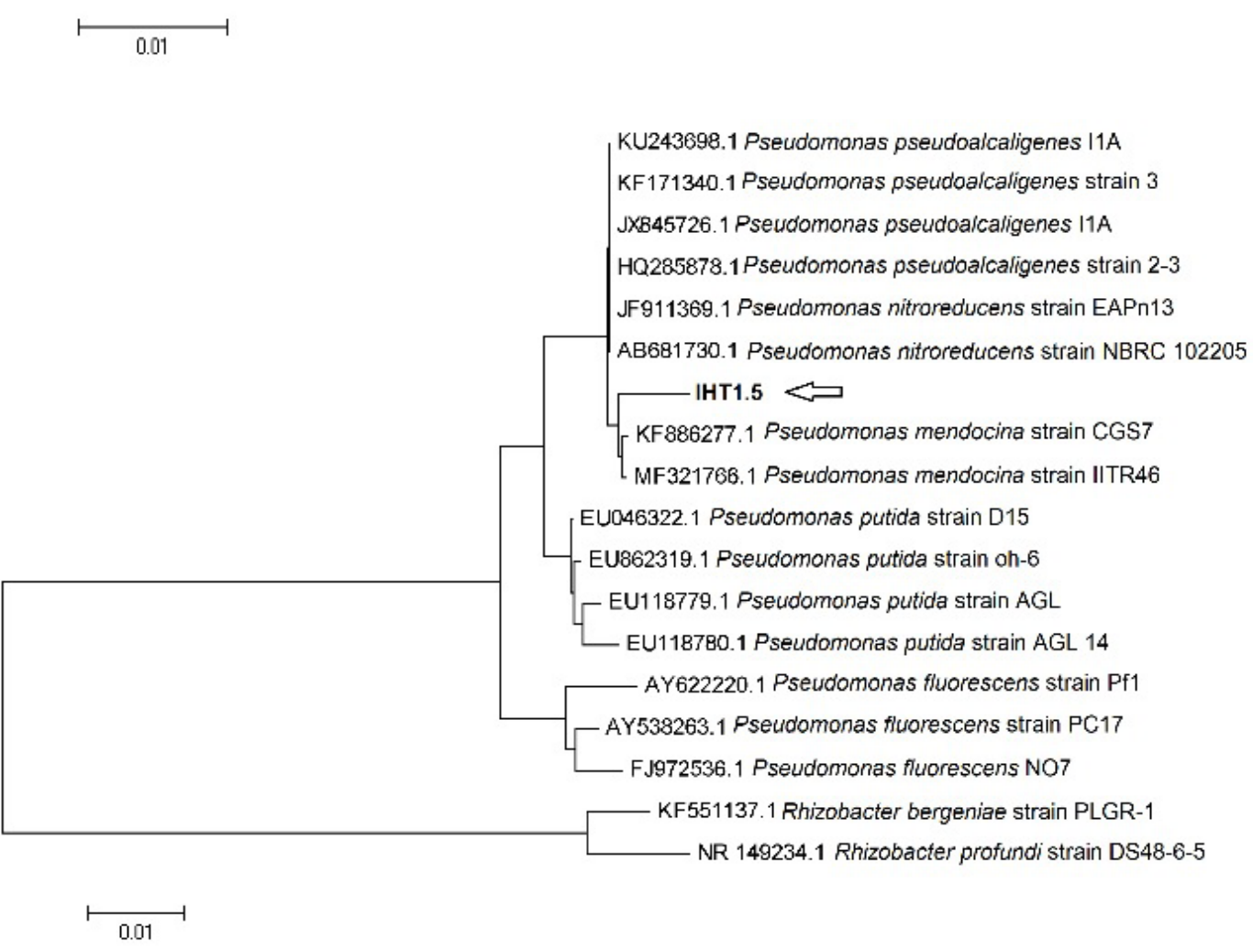




\section{Jurnal Biodjati 4(1):79-88, May 2019 \\ JURNAL BIDDJATI}

http://journal.uinsgd.ac.id/index.php/biodjati

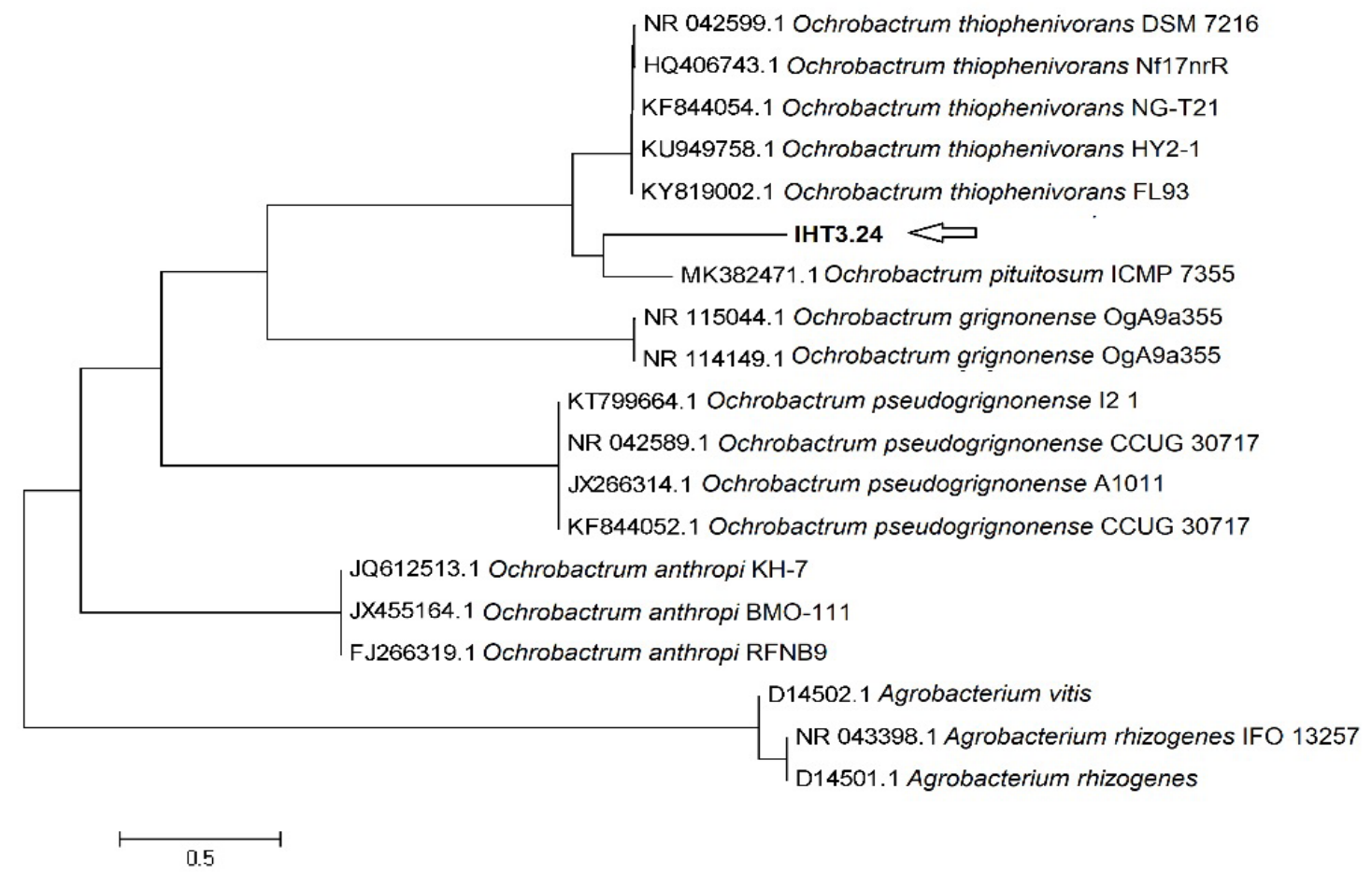

Figure 4. The phylogenetic tree of selected hydrocarboclastic bacteria with reference strains base on 16S rDNA sequence similarity according Neighbor-Joining algorithm and Tamura-Nei model Ochrobactrum pseudogrignonense (a), Pseudomonas mendocina (b) and Ochrobactrum pituitosum (c)

\section{ACKNOWLEDGMENTS}

This work was financially supported by the Kaltara scholarship 2018, the North Kalimantan Education Council.

\section{REFERENCES}

Al-Wasify, R. S. \& Hamed, S. R. (2014). Bacterial Biodegradation of Crude Oil Using Local Isolates. International journal of bacteriology.

Carrero-Colón, M., Nakatsu, C. H. \& Konopka, A. (2006). Effect of Nutrient Periodicity on Microbial Community Dynamics. Appl. Environ. Microbiol, 72(5), 3175-3183.

Chikere, C. \& Azubuike, C. (2014). Characterization of Hydrocarbon Utilizing Jurnal Biodjati 4(1):79-88, May 2019
Fungi from Hydrocarbon Polluted Sediments and Water. Nigerian Journal of Biotechnology, 27, 49-54.

Dealtry, S., Ghizelini, A. M., Mendonça-Hagler, L., Chaloub, R. M., Reinert, F., de Campos, T. M., ... Smalla, K. (2018). Petroleum Contamination and Bioaugmentation in Bacterial Rhizosphere Communities from Avicennia schaueriana. Brazilian Journal of Microbiology, 49(4), 757-769.

Gochhait, S., Malhotra, D., Rai, E. \& Bamezai, R. N. K. (2007). Automated Fluoroscence Sequencing and Troubleshooting. in Advanced Techniques in Soil Microbiology. Springer (pp. 35-51)

Guo, Y. Q., Liu, J.-X., Lu, Y., Zhu, W. Y., Denman, S. E. \& McSweeney, C. S. (2008). Effect of Tea Saponin on Methanogenesis, Microbial Community Structure and 


\section{Jurnal Biodjati 4(1):79-88, May 2019 \\ JURNAL BI@DIATI}

http://journal.uinsgd.ac.id/index.php/biodjati

Expression of mcrA Gene, in Cultures of Rumen Micro-organisms. Letters in Applied Microbiology, 47(5), 421-426.

Kobayashi, T., Kaminaga, H., Navarro, R.

R. \& Iimura, Y. (2012). Application of Aqueous Saponin on the Remediation of Polycyclic Aromatic Hydrocarbons-Contaminated Soil. Journal of Environmental Science and Health, Part A, 47(8), 1138-1145.

Kompas, K. (2016). Reserves Only 3.6 Billion Barrels, Exploration Needs to Be Enhanced. Diambil dari https://biz.kompas.com/read/2016/10/09/143111028/ cadangan.tinggal.3.6.miliar.barrel.eksplorasi.perlu.ditingkatkan

Kostka, J. E., Prakash, O., Overholt, W. A., Green, S. J., Freyer, G., Canion, A., ... Huettel, M. (2011). Hydrocarbon-Degrading Bacteria and the Bacterial Community Response in Gulf of Mexico Beach Sands Impacted by the Deepwater Horizon Oil Spill. Appl. Environ. Microbiol., 77(22), 7962-7974.

Lorenz, T. C. (2012). Polymerase Chain Reaction: Basic Protocol Plus Troubleshooting and Optimization Strategies. JoVE (Journal of Visualized Experiments), (63).

Marecik, R., Wojtera-Kwiczor, J., Ławniczak, Ł., Cyplik, P., Szulc, A., Piotrowska-Cyplik, A. \& Chrzanowski, Ł. (2012). Rhamnolipids Increase the Phytotoxicity of Diesel Oil Towards Four Common Plant Species in a Terrestrial Environment. Water, Air, \& Soil Pollu- tion, 223(7), 4275-4282.

Panda, J. \& Sarkar, P. (2012). Isolation and Identification of Chromium-Resistant Bacteria: Test Application for Prevention of Chromium Toxicity in Plant. Journal of Environmental Science and Health, Part A, 47(2), 237-244.

Promega. (2016). PCR Master Mix Protocol. USA: Madison.

Quatrini, P., Scaglione, G., De Pasquale, C., Riela, S. \& Puglia, A. M. (2008). Isolation of Gram Positive n-Alkane Degraders from a Hydrocarbon-Contaminated Mediterranean Shoreline. Journal of Applied Microbiology, 104(1), 251259.

Soeder, C. J., Papaderos, A., Kleespies, M., Kneifel, H., Haegel, F.-H. \& Webb, L. (1996). Influence of Phytogenic Surfactants (Quillaya Saponin and Soya Lecithin) on Bio-Elimination of Phenanthrene and Fluoranthene by Three Bacteria. Applied Microbiology and Biotechnology, 44(5), 654-659.

Udgire, M., Shah, N. \& Jadhav, M. (2015). Enrichment, Isolation and Identification of Hydrocarbon Degrading Bacteria. Int. J. Curr. Microbiol. App. Sci, 4(6), 708-713. 